\title{
DETEKTOR GAS OKSIGEN DARI BAHAN SEMIKONDUKTOR TiO2 DOPING CuO
}

\author{
Paradita Ramli*, Elvaswer \\ Jurusan Fisika Universitas Andalas \\ Email : Paraditaramli77@gmail.com
}

\begin{abstract}
ABSTRAK
Telah dilakukan karakterisasi detektor oksigen berupa pelet dengan bahan utama TiO2 didoping oleh $\mathrm{CuO}$. Pelet detektor oksigen dibuat dengan variasi doping $\mathrm{CuO} 0 \%, 2 \%, 4 \%, 6 \%$, 8\%, dan $10 \%$ terhadap bahan utama TiO2. Proses pembuatan detektor oksigen diawali dengan pencampuran bahan, kalsinasi pada temperatur $500^{\circ} \mathrm{C}$ selama 4 jam, penggerusan, kompaksi, dan sintering pada temperatur $700^{\circ} \mathrm{C}$ selama 4 jam. Detektor oksigen diuji pada temperatur ruang $\left(30^{\circ} \mathrm{C}\right)$ dengan melihat karakteristik I-V, nilai sensitivitas, nilai konduktivitas, waktu respon, dan karakterisasi XRD. Nilai sensitivitas tertinggi dihasilkan sampel $98 \%$ mol TiO2 $+2 \% \mathrm{~mol} \mathrm{CuO}$ sebesar 10,98 pada tegangan 30 volt dengan waktu respon 55 s. Nilai konduktivitas tertinggi dihasilkan oleh sampel $90 \%$ mol $\mathrm{TiO} 2+10 \%$ mol $\mathrm{CuO}$ pada lingkungan oksigen. Hasil XRD menunjukkan ukuran kristal sampel dengan doping lebih kecil daripada sampel tanpa doping. Pada doping $\mathrm{TiO} 2+6 \%$ mol $\mathrm{CuO}$ telah terbentuk senyawa baru dengan puncak $\mathrm{CuO}$.
\end{abstract}

Kata kunci: Detektor oksigen, $\mathrm{TiO} 2(\mathrm{CuO})$, sensitivitas, waktu respon, XRD.

\begin{abstract}
Oxygen detector characterization has been done in the form of pellets with the main ingredients of $\mathrm{TiO} 2$ doped by $\mathrm{CuO}$. The oxygen detector's pellets are made by varying doped of $\mathrm{CuO} 0 \%, 2 \%$, $4 \%, 6 \%, 8 \%$ and $10 \%$ of the main ingredients $\mathrm{TiO} 2$. The process of making oxygen detector begins with the mixing of materials, calcination temperatur of $500 \mathrm{oC}$ for 4 hours, grinding, compacting and sintering at $700 \mathrm{oC}$ for 4 hours. Oxygen detectors are tested at room temperature $(30 \mathrm{oC})$ by seeing the characteristics of $\mathrm{I}-\mathrm{V}$, sensitivity, conductivity, response time, and XRD characterization. The highest sensitivity value resulting from sample with $98 \%$ mol $\mathrm{TiO} 2+2 \%$ $\mathrm{mol} \mathrm{CuO}$ at 10,98 at a voltage of 30 volts with a response time $55 \mathrm{~s}$. The highest conductivity value resulting from the sample $90 \% \mathrm{~mol} \mathrm{TiO} 2+10 \% \mathrm{~mol} \mathrm{CuO}$ in oxygen environment. XRD results showed the crystal size of sample by doping is smaller than the sample without doping. At doping $\mathrm{TiO} 2+6 \% \mathrm{~mol} \mathrm{CuO}$ has formed a new compound with the peak of $\mathrm{CuO}$.
\end{abstract}

Keywords : Oxygen detector, $\mathrm{TiO} 2(\mathrm{CuO})$, sensitivity, response time, XRD.

\section{PENDAHULUAN}

Udara dalam bumi mengandung banyak unsur. Salah satu dari unsur tersebut adalah gas oksigen. Gas oksigen merupakan unsur kedua yang banyak ditemukan di atsmosfer, yaitu nitrogen 78,08\%, oksigen 20,95\% dan 0,97\% unsur lainnya (Cook \& Lauer 1968). Oksigen berasal dari hasil fotosintesis tumbuhan yang berperan penting dalam sistem pernafasan manusia.

Keberadaan oksigen tidak hanya berperan secara biologis tapi juga industri, salah satunya sebagai bahan bakar roket (NASA, 1926). Penggunaan gas oksigen lainnya adalah untuk keperluan medis di rumah sakit. Oksigen disimpan dalam sebuah tabung baja dimana oksigen yang terkandung didalamnya adalah oksigen murni yang kemudian disimpan dalam ruangan khusus dan tertutup. Tabung yang berisi oksigen merupakan tabung gas bertekanan tinggi sehingga berbahaya apabila terjadi kebocoran seperti terbakar dan 
meledak. Oksigen merupakan gas yang mudah terbakar karena sifatnya yang reaktif, oksigen juga tidak berbau, tidak berwarna dan tidak berasa sehingga sulit untuk mengetahui bahwa telah terjadi kebocoran (Matheson Tri Gas, 2000).

Kebakaran akibat kebocoran gas oksigen dapat dicegah dengan membuat suatu detektor gas oksigen menggunakan material semikonduktor yang sensitif terhadap gas oksigen dan terbuat dari bahan logam oksida seperti $\mathrm{TiO} 2, \mathrm{ZnO}, \mathrm{CuO}, \mathrm{SnO}$. Bahan logam oksida dapat mendeteksi berbagai gas karena akan bereaksi dengan gas yang dapat merubah stoikiometri bahan oksida tersebut jika menyerap ion-ion gas. Perubahan stoikiometri bahan akan mengakibatkan perubahan konduktivitas pada bahan logam oksida (Akbar, 1997).

Bahan TiO2 merupakan bahan logam oksida yang banyak digunakan dalam berbagai aplikasi sensor gas karena memiliki sifat seperti stabilitas kimia, transfer muatan dan sifat listrik yang baik (Yadav, dkk., 2011). Material TiO2 dikenal tidak beracun, memiliki stabilitas termal cukup tinggi dan kemampuannya dipergunakan berulang kali tanpa kehilangan aktivitas katalitiknya. Peningkatan sifat mekanik, sifat elektronik dan sifat katalitik material $\mathrm{TiO} 2$ dapat diupayakan melalui pembentukannya dalam skala molekular atau dikenal sebagai nanopartikel (Fatimah, 2009).

Sebelumnya telah dilakukan penelitian mengenai sensor gas oksigen menggunakan bahan titanium $(\mathrm{TiO} 2)$ doping niobium $(\mathrm{Nb})$ menggunakan metode solid state reaction oleh Sharma (1998). Hasil penelitian menunjukan nilai sensitivitas $\mathrm{TiO} 2$ yang didoping dengan $\mathrm{Nb}$ adalah 3 pada temperatur $400 \mathrm{oC}$ dengan waku respon $3 \mathrm{~s}$, sensitivitas yang dihasilkan dengan didoping lebih besar dibandingkan tanpa doping. SEM menunjukkan bahwa ukuran kristal dengan doping lebih kecil dibandingkan tanpa doping.

Penelitian sensor gas oksigen lainnya juga dilakukan oleh Wang (2014) menggunakan $\mathrm{TiO} 2$ dan $\mathrm{Pd}$ dengan metode film tipis. Hasil dari penelitian menunjukkan sensitivitas meningkat pada bahan TiO2 yang dilapisi Pd sebesar 0,054 dengan deviasi 2,56 x 10-4, waktu respon rata-rata adalah $52 \mathrm{~s}$, hasil SEM memperlihatkan bahan $\mathrm{TiO} 2$ / $\mathrm{Pd} / \mathrm{TiO} 2$ memiliki ukuran yang lebih kecil atau nanopartikel dengan luas permuakaan yang lebih besar dan kekasaran lebih kecil.

Penelitian ini menggunakan bahan semikonduktor $\mathrm{TiO} 2$ yang didoping $\mathrm{CuO}$ untuk meningkatkan sensitivitas dan menurunkan suhu operasi.

\section{METODE}

\subsection{Pembuatan Pelet}

Penelitian ini dilakukan dengan menggunakan enam variasi persentase doping $\mathrm{CuO}$ (Merck, Jerman) yaitu $0 \%, 2 \%, 4 \%, 6 \%, 8 \%$ dan 10\% mol terhadap bahan dasar TiO2 (Merck, Jerman). Ukuran sampel pelet yang di uji berdiameter $11 \mathrm{~mm}$ dan tebal 2,5 $\mathrm{mm}$.

Persamaan reaksi kimia yang digunakan untuk mendapatkan massa sampel pada penelitian ini adalah :

$$
x \mathrm{CuO}+(1-X) \mathrm{TiO}_{2} \rightarrow \mathrm{Cu}_{x} \mathrm{Ti}_{(1-x)} \mathrm{O}_{(2-X)}
$$

$\mathrm{x}$ adalah jumlah doping yang ditambahkan dalam mol

Bahan sampel digerus digerus selama kurang lebih kurang 2 jam hingga diperkirakan sudah homogen, kemudian dikalsinasi pada suhu $500{ }^{\circ}$ Cselama 4 jam, selanjutnya bahan dikompaksi lalu disintering pada suhu $700{ }^{\circ} \mathrm{Cselama} 4$ jam (Dewi, 2014). 


\subsection{Karakterisasi $I-V$}

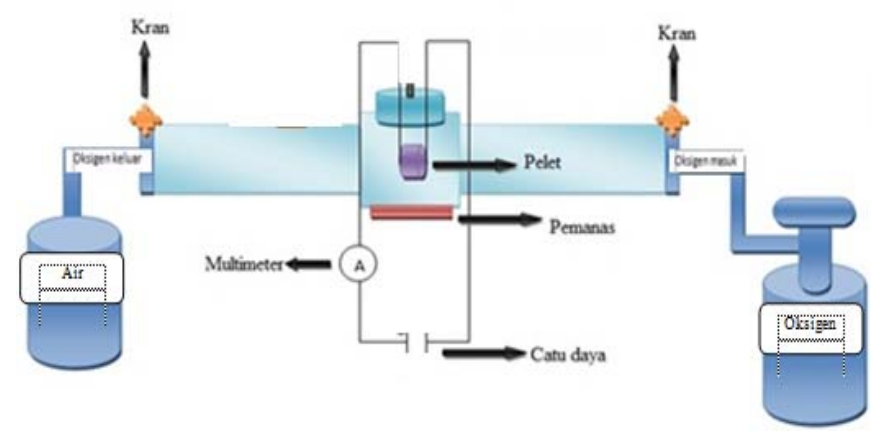

Gambar 1 Skema rangkaian alat pengujian sensor gas oksigen

Pelet yang telah disintering dikarakterisasi menggunakan alat pengujian sensor gas seperti yang ditunjukan oleh Gambar 1. Ketika dilakukan penelitian, gas oksigen dialirkan dengan kecepatan alir gas oksigen yang diatur menggunakan regulator dengan kecepatan 120 gel/detik. Pengkarakterisasian dilakukan dalam temperatur ruang yang diberi tegangan dalam bentuk bias maju dan bias mundur yang terhubung dengan salah satu bagian elektroda pada sampel holder dan multimeter. Pengukuran karakteristik I-V dilakukan dengan memberikan variasi tegangan dari 30 volt sampai -30 volt dengan interval 5 volt.

Pengukuran karakteristik I-V akan menentukan nilai sensitivitas dan nilai konduktivitas detektor. Nilai sensitivitas dan konduktivitas dapat diketahui dengan melakukan perhitungan dengan menggunakan rumus :

$$
\begin{gathered}
s=\frac{I_{O}}{I_{u}} \\
\sigma=\frac{L}{R A}
\end{gathered}
$$

Dengan $\mathrm{S}$ adalah sensitivitas, Io adalah arus dilingkungan oksigen, $\mathrm{Iu}$ adalah arus dilingkungan udara, $\sigma$ adalah konduktivitas, $\mathrm{L}$ adalah tebal sampel, $\mathrm{R}$ adalah resistansi, dan A adalah luas penampang.

\section{HASIL DAN DISKUSI}

\subsection{Analisis Karakterisasi XRD}

Karakterisasi XRD pada penelitian ini dilakukan pada dua sampel yaitu $100 \% \mathrm{TiO}_{2}$ dan sampel $94 \% \mathrm{TiO}_{2}+6 \% \mathrm{CuO}$. Pola difraksi XRD kedua sampel ditunjukkan pada Gambar 2. 


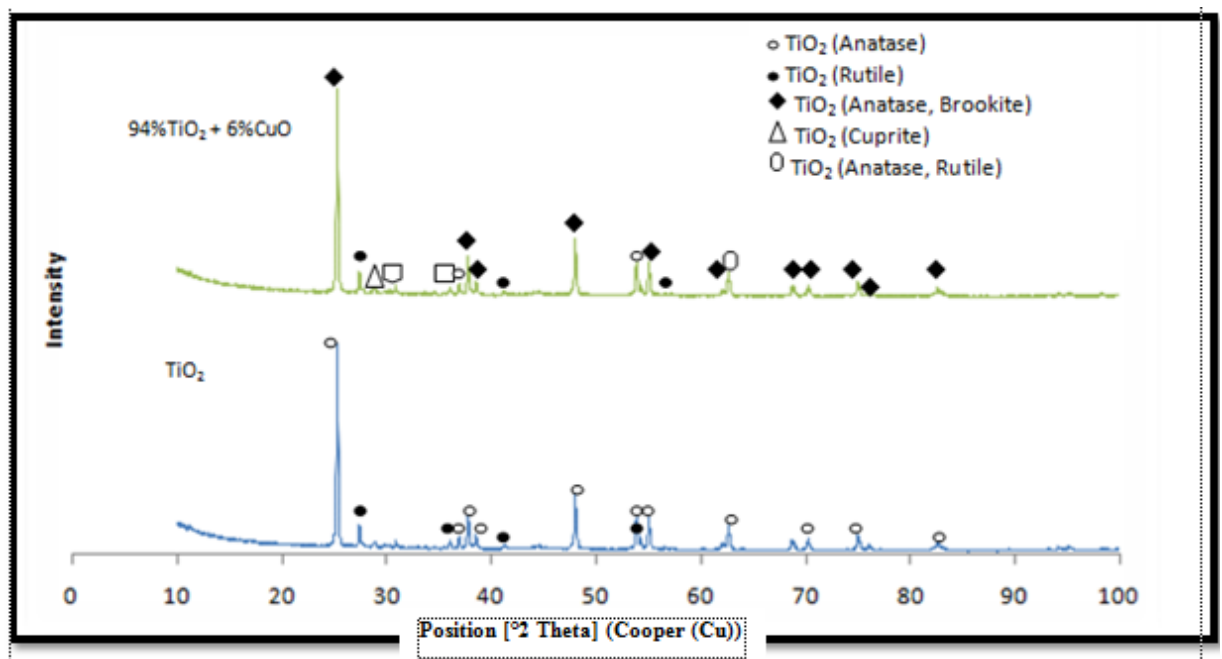

Gambar 2 Grafik Pola difraksi XRD pada sampel 100\% $\mathrm{mol} \mathrm{TiO}_{2}$ dan sampel 94\% mol $\mathrm{TiO}_{2}+6 \% \mathrm{~mol} \mathrm{CuO}$

Karakterisasi XRD dilakukan pada kedua sampel untuk melihat perbandingan struktur kristal antara $\mathrm{TiO}_{2}$ murni dengan $\mathrm{TiO}_{2}$ yang didoping. Salah satu sampel doping yang dikarakterisasi adalah $94 \% \mathrm{~mol} \mathrm{TiO}_{2}+6 \% \mathrm{~mol} \mathrm{CuO}$. Pengkarakterisasian dilakukan dengan tujuan untuk melihat perubahan struktur kristal dan senyawa baru yang muncul antara sampel yang didoping dan tanpa doping.

Pada Gambar 2 dapat dilihat bahwa sampel 100\% mol $\mathrm{TiO}_{2}$ memiliki puncak tertinggi dalam bentuk anatase dengan puncak lainnya dalam bentuk rutile. Sedangkan untuk sampel 94\% mol $\mathrm{TiO}_{2}+6 \%$ mol $\mathrm{CuO}$ didapatkan puncak-puncak seperti anatase rutile, dan yang didominasi puncak tertinggi yaitu anatase brookite serta terbentuknya senyawa baru dengan munculnya puncak yang baru yaitu cuprite.

Bahan $\mathrm{TiO}_{2}$ yang diberi doping $\mathrm{CuO}$ mempengaruhi ukuran kristal $\mathrm{TiO}_{2}$. Ukuran kristal pada $100 \% \mathrm{TiO}_{2}$ dengan $\mathrm{FWHM}$ pada intensitas tertinggi yaitu 6631,07 adalah 127,38 nm. Ukuran kristal $\mathrm{TiO}_{2}$ didoping dengan $6 \%$ mol $\mathrm{CuO}$ dengan FWHM pada intensitas tertinggi adalah $118,42 \mathrm{~nm}$. Ukuran kristal $\mathrm{TiO}_{2}$ yang didoping dengan $6 \% \mathrm{~mol} \mathrm{CuO}$ lebih kecil dibandingkan dengan $\mathrm{TiO}_{2}$ tanpa doping. Hal ini disebabkan karena ketika bahan diberikan doping, masing-masing bahan saling membelah diri sehingga terjadinya pertumbuhan kristal yang membuat ukuran kristal menjadi lebih kecil.

\subsection{Karakteristik I-V Sampel pada Lingkungan Udara dan Oksigen}

Nilai karakteristik I-V didapat dengan mengukur besar arus dan tegangan pada masingmasing sampel. Karakteristik I-V berupa grafik yang menunjukan perbedaan nilai arus dan tegangan pada lingkungan udara dan lingkungan oksigen. Karakteristik I-V untuk sampel 100\% mol $\mathrm{TiO}_{2}$ tanpa doping ditunjukan oleh Gambar 3. 


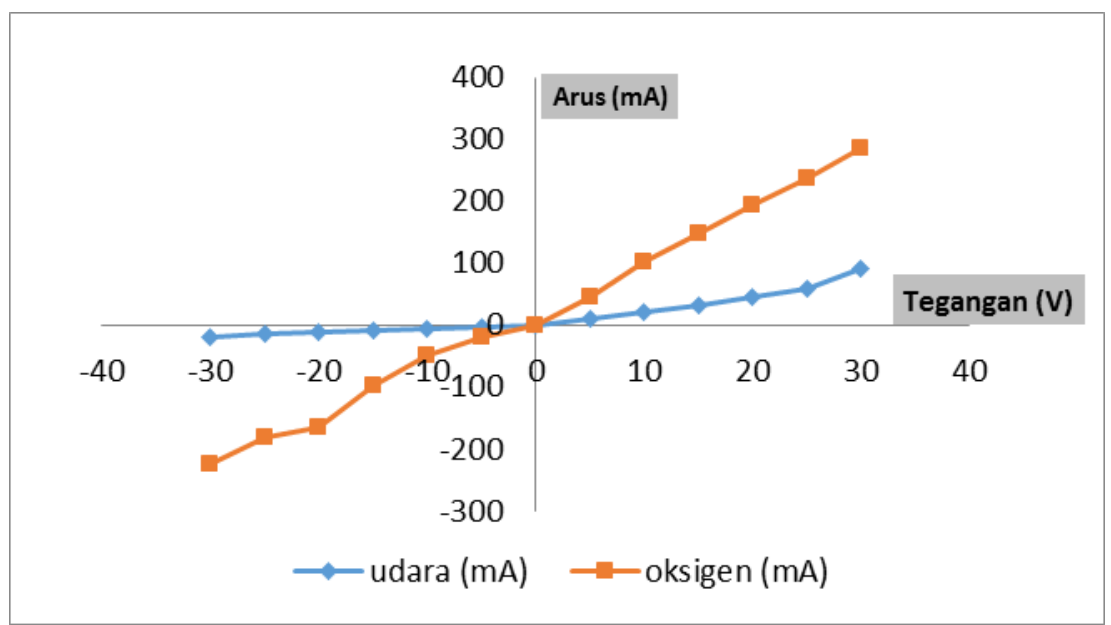

Gambar 3 Grafik I-V 100\% mol $\mathrm{TiO}_{2}$

Grafik I-V pada Gambar 3 menunjukan bahwa nilai arus meningkat seiring dengan meningkatnya tegangan. Bahan detektor diasumsikan sebagai dioda namun tidak berprilaku seperti dioda. Karena menghasilkan karakteristik grafik yang linier.

Arus pada lingkungan oksigen lebih tinggi dibandingkan lingkungan udara yang disebabkan karena reaksi yang terjadi antara oksigen dan oksida yang ada pada permukaan partikel $\mathrm{TiO}_{2}$ yang mengakibatkan berkurangnya lebar pada daerah deplesi sehingga elektron mudah untuk melompat dari pita valensi ke pita konduksi. Nilai arus pada bias maju juga lebih besar dibanding bias mundur. Hal ini terjadi karena pada bias maju terjadi pengecilan daerah deplesi akibat adanya pengurangan antara tegangan kontak dengan tegangan bias maju. Sedangkan pada bias mundur arus kecil karena adanya penambahan tegangan kontak dengan tegangan bias mundur, sehingga terjadi pelebaran pada daerah deplesi yang membuat elektron sulit melompat.

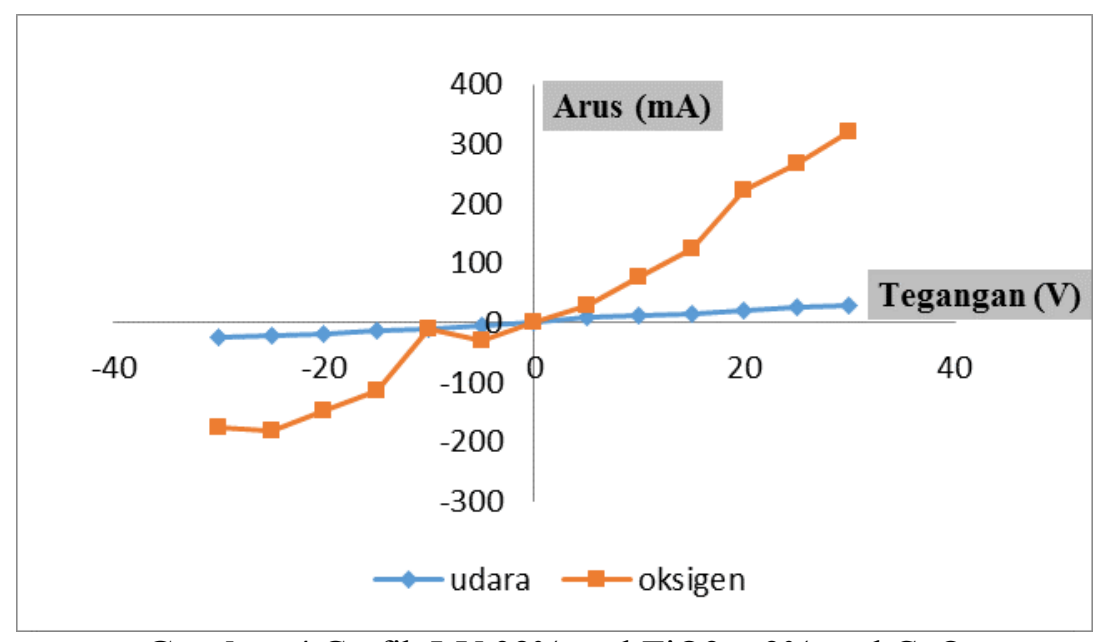

Gambar 4 Grafik I-V 98\% mol TiO2 + 2\% mol CuO

Sampel $\mathrm{TiO}_{2}$ yang didoping dengan $2 \%$ mol CuO pada Gambar 4 menunjukan bahwa nilai arus pada lingkungan oksigen lebih tinggi dibandingkan dengan sampel tanpa doping pada Gambar 4. Ini disebabkan oleh efek doping antara $\mathrm{TiO} 2$ dengan $\mathrm{CuO}$ yang kelebihan dua hole dapat memperkecil energi gap dengan munculnya energi aseptor. Seperti yang ditunjukan persamaan reaksi kimia berikut. 


$$
\mathrm{Ti}^{4+} \mathrm{O}_{2}{ }^{2-}+\mathrm{Cu}^{2+} \mathrm{O}^{2-} \rightarrow \mathrm{CuTiO}_{3}+2 e^{+}
$$

Selain itu juga terjadi reaksi antara oksigen dengan oksida material yang melepaskan satu elektron bebas yang berperan sebagai pembawa muatan. Sampel $\mathrm{TiO}_{2}$ yang didoping $2 \%$ mol $\mathrm{CuO}$ merupakan sampel dengan perbandingan arus pada lingkungan oksigen dengan lingkungan udara paling besar.

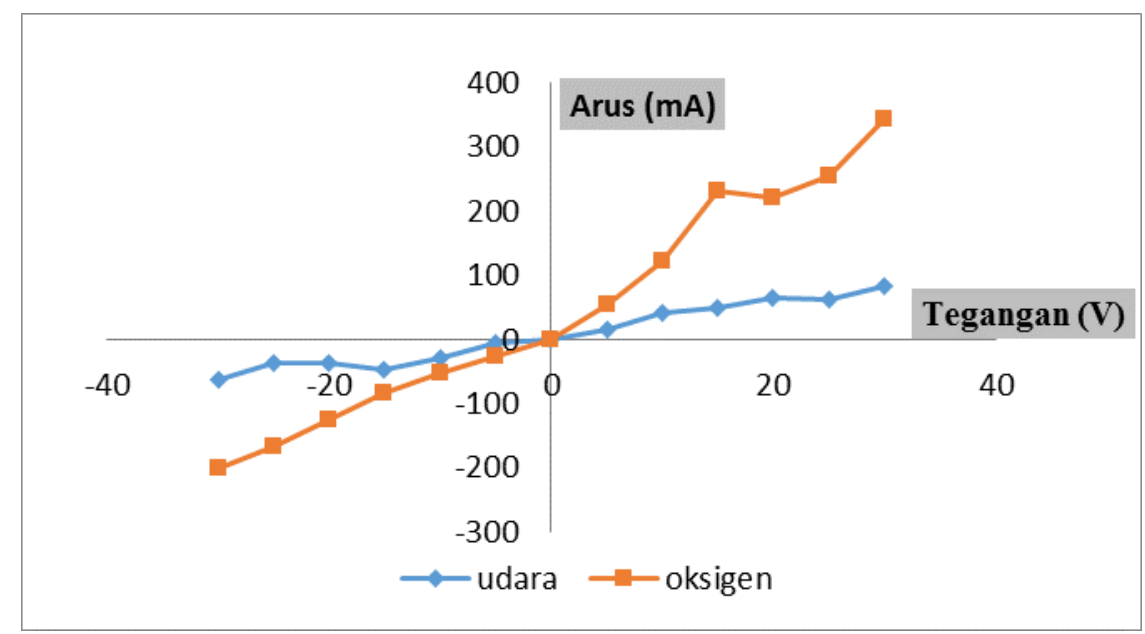

Gambar 5 Grafik I-V 96\% mol $\mathrm{TiO}_{2}+4 \% \mathrm{~mol} \mathrm{CuO}$

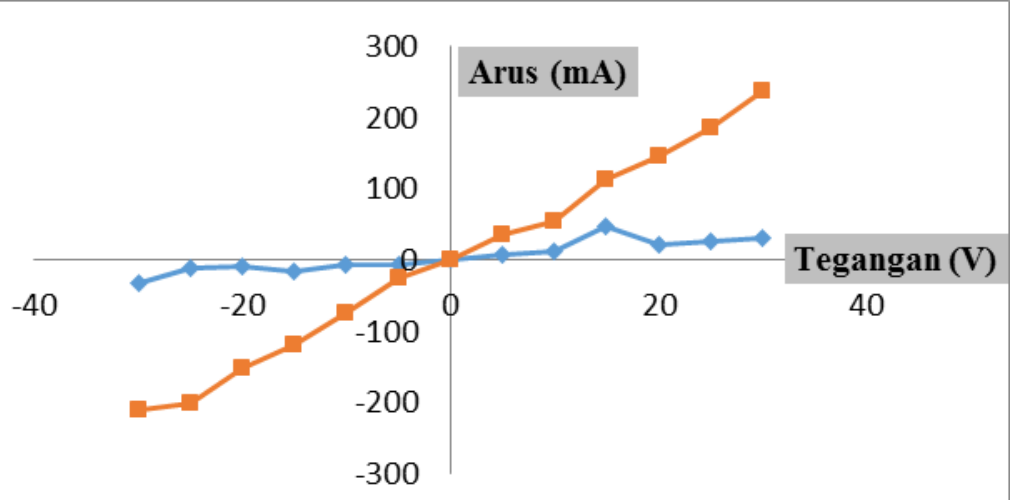

Gambar 6 Grafik I-V 94\% mol $\mathrm{TiO}_{2}+6 \% \mathrm{~mol} \mathrm{CuO}$

Grafik pada Gambar 5 dan Gambar 6 memperlihatkan besar arus yang terus meningkat baik ketika berada dilingkungan udara maupun dilingkungan oksigen. Semakin besar doping yang diberikan maka daerah deplesi akan semakin mengecil sehingga elektron semakin mudah melompat yang berakibat nilai arus menjadi semakin besar. Arus pada lingkungan oksigen masih tinggi dibandingkan arus pada lingkungan udara karena reaksi antara oksigen dan oksida pada permukaan partikel masih terjadi. 


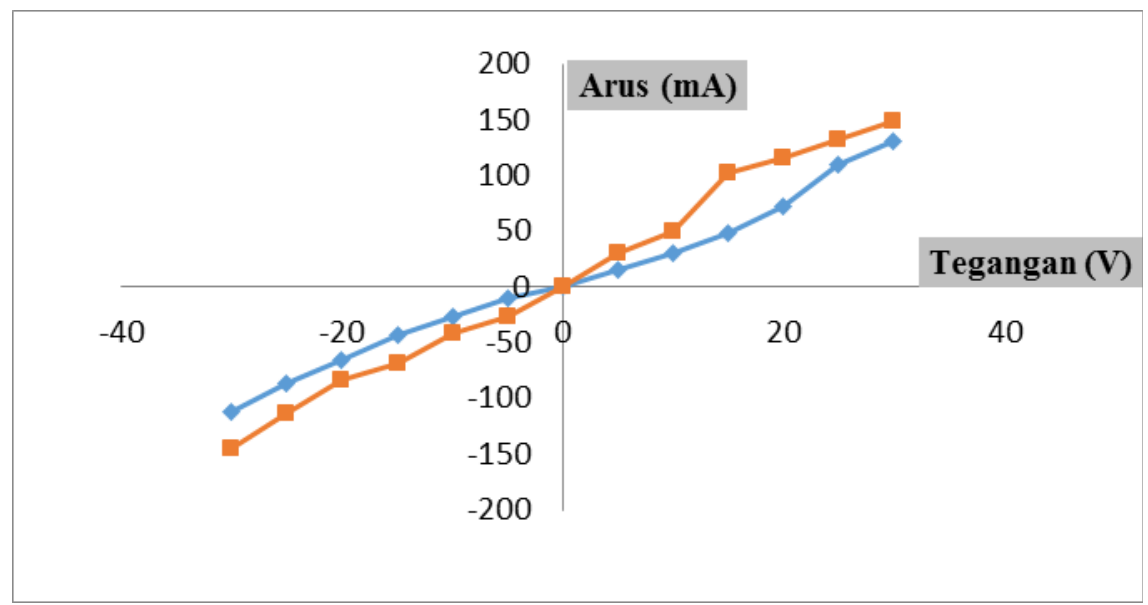

Gambar 7 Grafik I-V 92\% mol $\mathrm{TiO}_{2}+8 \% \mathrm{~mol} \mathrm{CuO}$

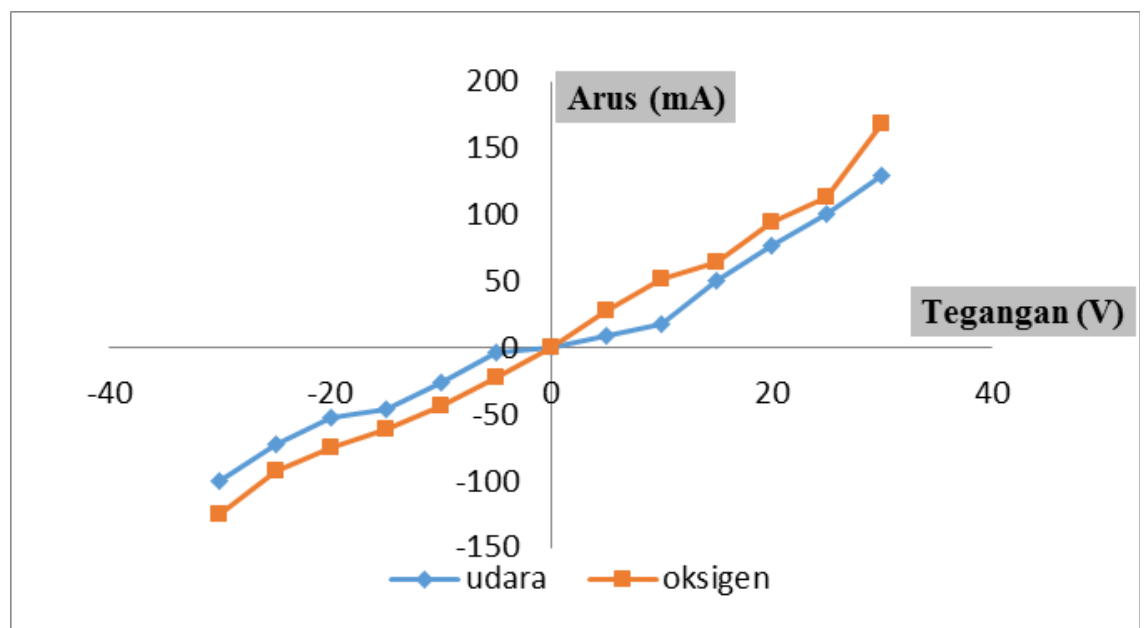

Gambar 8 Grafik I-V 90\% mol $\mathrm{TiO}_{2}+10 \% \mathrm{~mol} \mathrm{CuO}$

Gambar 7 dan Gambar 8 menunjukan arus pada lingkungan oksigen tidak jauh berbeda dengan lingkungan udara dibandingkan dengan sampel tanpa doping. Hal ini disebabkan oleh doping yang berlebihan dapat mengakibatkan kemungkinan yang terjadi bukanlah kontak antar muka antara partikel $\mathrm{TiO}_{2}$ dengan $\mathrm{CuO}$ melainkan partikel doping $\mathrm{CuO}$ kontak antar muka dengan $\mathrm{CuO}$ sehingga reaksi yang terjadi antara oksigen dan oksida pada permukaan sampel sedikit.

\subsection{Karakteristik Konduktivitas}

Hasil konduktivitas dapat dilihat berdasarkan Gambar 9 


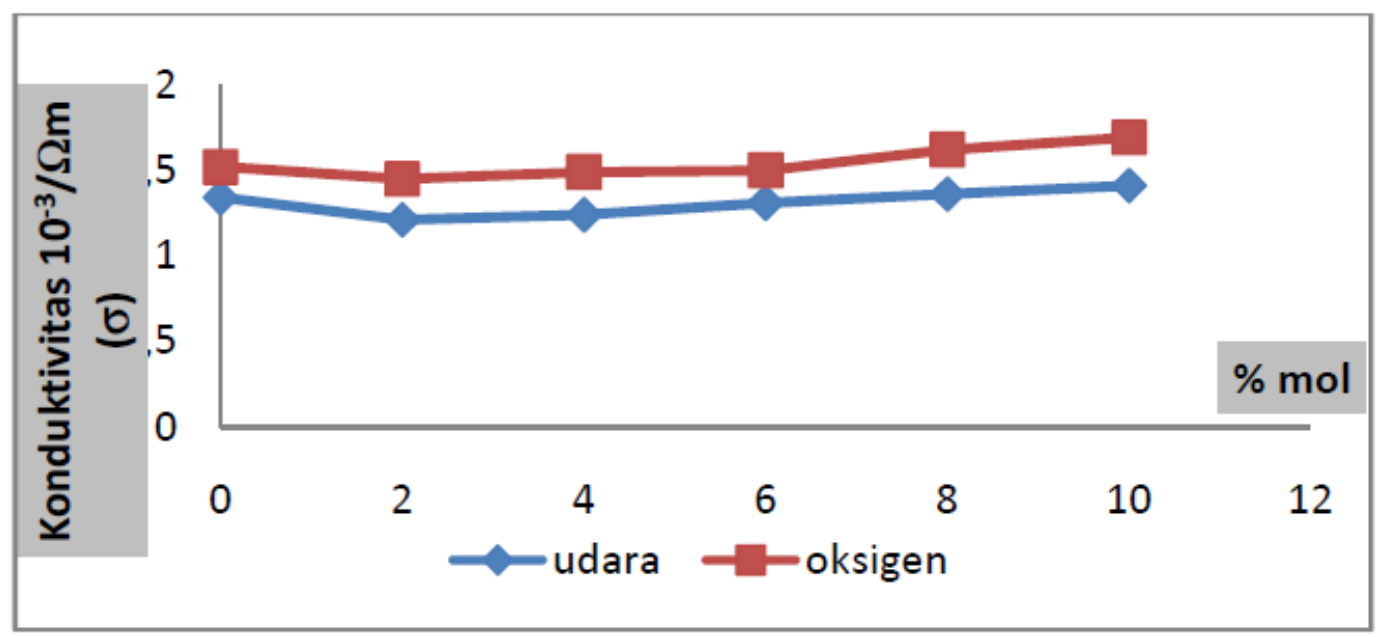

Gambar 9 Grafik perubahan konduktivitas dilingkungan oksigen dan udara

Gambar 9 memperlihatkan bahwa nilai konduktivitas pada lingkungan oksigen lebih tinggi dibandingkan pada lingkungan udara. Hal ini terjadi karena reaksi antara oksigen dan oksida pada permukaan partikel sampel lebih banyak terjadi ketika sampel berada pada lingkungan oksigen.

Konduktivitas tertinggi diperoleh pada sampel dengan doping $10 \%$ mol $\mathrm{CuO}$. Hal ini disebabkan oleh banyaknya penambahan doping akan menyebabkan elektron memperoleh cukup energi untuk melewati daerah deplesi. Berdasarkan hasil XRD, penambahan doping pada bahan akan memperkecil ukuran kristal sehingga partikel $\mathrm{TiO}_{2}$ dan $\mathrm{CuO}$ akan lebih terpusat yang menyebabkan batas butir antar keduanya semakin mengecil sehingga elektron dapat berpindah dari pita valensi ke pita konduksi.

\subsection{Karakteristik Sensitivitas}

Berdasarkan karakterisasi I-V dari keenam sampel yang telah diukur, didapatkan sebuah grafik perubahan sensitivitas terhadap tegangan. Seperti yang terlihat pada Gambar 10.

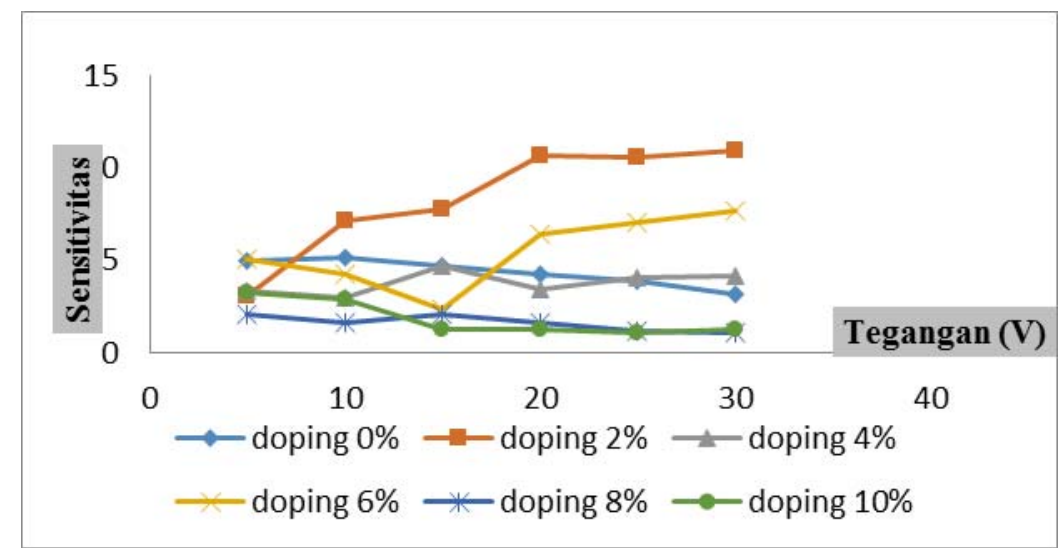

Gambar 10 Grafik perubahan sensitivitas terhadap tegangan

Berdasarkan Gambar 10 terlihat bahwa pada tegangan 5V sampel yang memiliki sensitivitas tertinggi adalah sampel dengan doping $6 \% \mathrm{~mol} \mathrm{CuO}$. Namun ketika diberi tegangan besar dari $5 \mathrm{~V}$ sensitivitas cenderung menurun. Sedangkan sensitivitas dengan tegangan $10 \mathrm{~V}$ hingga $30 \mathrm{~V}$ diperoleh sensitivitas paling tinggi dimiliki oleh sampel dengan doping $2 \%$ mol $\mathrm{CuO}$ dengan perolehan sensitivitas tertinggi pada tegangan $30 \mathrm{~V}$ 
yaitu 10,98. Hal ini disebabkan karena kemungkinan hubungan antar muka antara $\mathrm{TiO}_{2}$ dengan doping $\mathrm{CuO}$ paling optimum.

Sampel dengan konduktivitas tertinggi yaitu dengan doping $10 \%$ mol $\mathrm{CuO}$ memiliki besar sensitivitas yang rendah. Hal ini disebabkan karena penambahan doping yang banyak akan menimbulkan hubungan antar muka antara $\mathrm{CuO}$ dengan $\mathrm{CuO}$ yang menyebabkan reaksi antara oksigen dan oksida sedikit sehingga nilai sensitivitas menurun.

\subsection{Karakterisasi Waktu Respon}

Waktu respon diambil dari sampel dengan nilai sensitivitas tertinggi yaitu pada sampel dengan doping $2 \%$. Waktu respon yang dimiliki oleh sampel $98 \% \mathrm{~mol}^{\mathrm{TiO}_{2}}+2 \% \mathrm{~mol}$ $\mathrm{CuO}$ pada tegangan $30 \mathrm{~V}$ dapat dilihat pada Gambar 11.

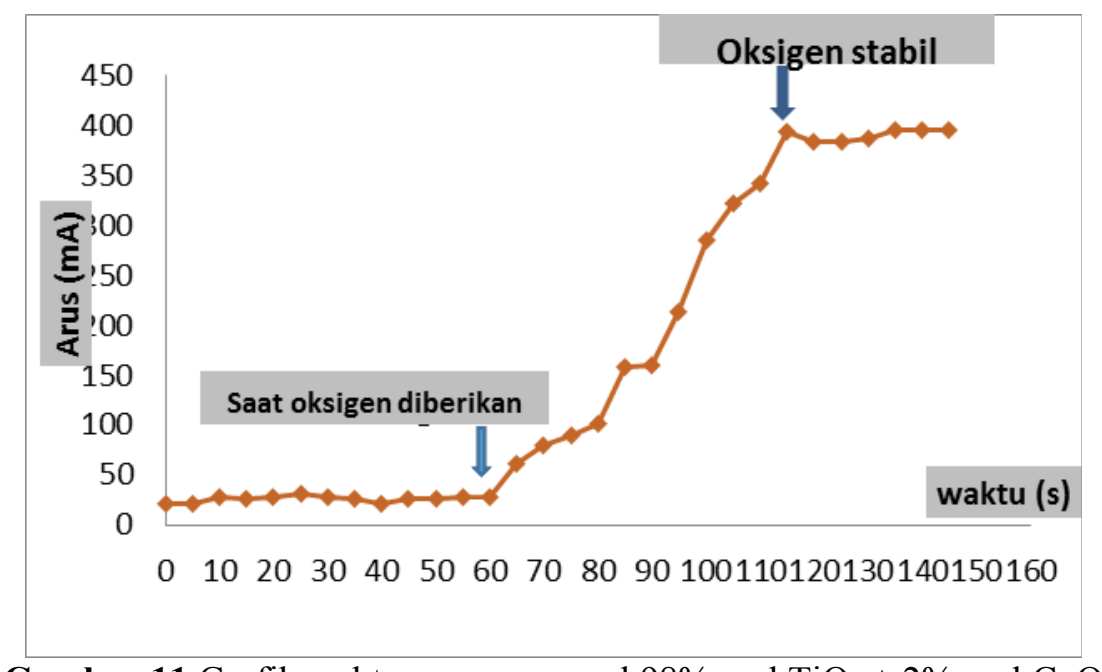

Gambar 11 Grafik waktu respon sampel 98\% $\mathrm{mol} \mathrm{TiO}_{2}+2 \% \mathrm{~mol} \mathrm{CuO}$

Sampel dibiarkan pada lingkungan udara hingga stabil pada detik ke-60. Oksigen mulai dialirkan dan terus meningkat. Sampel dibiarkan pada lingkungan oksigen hingga stabil pada detik ke-115. Besarnya waktu respon diperoleh dari awal terjadinya perubahan arus ketika oksigen dialirkan sampai arus pada lingkungan oksigen stabil. Dari hasil grafik didapatkan waktu respon yang dimiliki oleh sampel $98 \% \mathrm{~mol} \mathrm{TiO}_{2}+2 \%$ mol $\mathrm{CuO}$ adalah selama $55 \mathrm{~s}$.

\section{KESIMPULAN}

Penelitian ini menunjukkan bahwa detektor sudah mampu membedakan kondisi lingkungan udara dengan lingkungan Oksigen. Nilai sensitivitas tertinggi terdapat pada sampel 98\% mol $\mathrm{TiO} 2+2 \%$ mol CuO yaitu 10,98. Sampel ini merupakan sampel yang paling baik digunakan sebagai detektor gas Oksigen. Konduktivitas pada lingkungan Oksigen lebih tinggi dibandingkan pada lingkungan udara. Konduktivitas tertinggi dimiliki oleh sampel $90 \% \mathrm{~mol} \mathrm{TiO} 2+10 \%$ mol CuO dengan nilai konduktivitas yaitu $1,69 \times 10-3 / \Omega \mathrm{m}$. Waktu respon sampel $98 \% \mathrm{~mol} \mathrm{TiO} 2+2 \%$ mol $\mathrm{CuO}$ pada tegangan 30 volt adalah $55 \mathrm{~s}$. Hasil XRD menunjukkan terbentuknya senyawa baru dengan munculnya puncak $\mathrm{CuO}$. Ukuran kristal $\mathrm{TiO} 2$ yang didoping $6 \%$ mol $\mathrm{CuO}$ lebih kecil dibandingkan dengan $\mathrm{TiO} 2$ tanpa doping. 


\section{DAFTAR PUSTAKA}

1. Akbar, A.S., 1997, Sensing Mechanism of a Carbon Monoxide Sensor Based on Anatase Titania, Journal Electrochemistry Society, Vol 144 No.5.

2. Cook, G.A., Lauer, C.M., 1968, The encyclopedia of the chemical elements, Reinhold book Corporation, New york.

3. Dewi, R.S., 2014, Karakterisasi sensor gas lpg (Liquefied Petroleum Gas) dari bahan komposit semikonduktor TiO2(CuO), skripsi, Program Studi S-1 Fisika, Fakultas Matematika dan Ilmu Pengetahuan Alam, Universitas Andalas, Padang.

4. Fatimah, Is., Dispersi $\mathrm{TiO} 2$ ke dalam SiO2-montmorillonit : Efek Jenis Prekursor, Jurnal Penelitian Saintek, Vol.14, No.1, April 2009.

5. Sharma, R.K., 1996, Mechanism in Nb doped titania oxygen gas sensor, journal, department of physic, indian institute of technology, New Delhi, India, hal 194-201.

6. Wang, H., Chen, L., Sun,Q., Wang, J., Zhao, Y., 2014, A micro oxygen sensor based on a nano sol gel TiO2 thin film, journal, Xia'an jiaotong University, Shaanxi, China, hal 16423-16433.

7. Wismadi, T., 2001, Pembuatan dan Karakterisasi Lapisan Tipis Copper Oxide (CuO) Sebagai Sensor Gas, Skripsi, Program S-1 Fisika, Fakultas Matematika dan Ilmu Pengetahuan Alam, Institut Pertanian Bogor, Bogor.

8. Yadav, B. C., Yadav, A., Shukla, T., dan Singh, S., 2011, Solid-state Titania-based Gas Sensor for Liquefied Petroleum Gas Detection at Room Temperature, Bull. Mater. Sci., Vol.34, No. 7, hal. 1639-1644.

9. Matheson Tri Gas, 2000. Liquid Oxygen Material Safety Data Sheet. https://www.mathesongas.com/pdfs/msds/00225011.pdf. diakses juli 2015.

10. NASA, 1926. First Flight Of a Liquid Propellant Rocket. http://grin.hq.nasa.gov/ABSTRACTS/GPN-2002-000132.HTML. diakses pada 1 agustus 2015. 